\title{
Assessing the Processes and Programmes Undertaken to Facilitate International Trade by Ghana Shippers Authority
}

\author{
Stevens Justice Avenyo* Andrews Seidu Achana \\ University of Professional Studies, Accra, P.O. Box LG 149 Legon, Ghana \\ Faculty of IT and Communication Studies, Department of Communication Studies
}

\begin{abstract}
International trade has been one of the major factors that any developing economy has benefited from in diverse areas. Ghana, which is known to be the gateway to Africa has received enormous trade facilities through the country's Maritime Authority. This study took a step in the maritime industry to assess how international trade does affect the shipping industry and to investigate measures undertaken by the country to facilitating international trade. The study, however, gave depth insight in facilitating international trade in Ghana shippers' authority. The target population for the study were persons at various levels of management of the Ghana Shipping Authority (GSA). Thirty (30) respondents were used for the study. The study had a blend of qualitative and quantitative research design to make it flexible for the researchers to gather enough data for it. The findings revealed that the Shippers Authority in Ghana is financed through the revenue it generates from its operations, publications and warehousing (Facilitation of trade, rendering of Freight Service, Mobiship). And again, the Authority has also instituted various programmes that enhance their trade globally such as the MOU with landlocked countries in West Africa and the Union of African Shippers. All these activities have brought about transformation in developing the trade countries in the area of good transport systems, harmonizing of shipping and policies, axle load regime and international facilitation of forums: MOWCA, IMO and the World Shippers forum. Programmes such as the Ghana Community Network (GCNet) and Sealed Grid System (SGS) are also being used by the authority to track secure passage of transit cargo.
\end{abstract}

Keywords: International Trade, Ghana shipper Authority, Maritime, Import and Export

DOI: $10.7176 / \mathrm{IAGS} / 76-04$

Publication date:September $30^{\text {th }} 2019$

\section{Introduction}

The development in worldwide exchange (International trade), expulsion of exchange obstructions being the primary reason, has made the developing nations to focus more on the change of their framework, like roads, airports, seaports, which assume an essential job in the improvement of the economy (Schuppan 2009). Tomlin \& Wang (2011), Item stockpiling, alongside the ability to move expansive shipments, has set the transportation business in an extremely favorable position. Containerization, multi-modular trans-port administrations, the headway of marine designing innovation, specific frameworks; (Buyonge \& Kireeva 2008) and computerization have contributed towards making ocean transport as a prime means of development of globally exchanged merchandise (Czinkota et al. 2009). Nonetheless, the improvement of shipping industry in a nation likewise relies upon its populace thickness, financial headway and numerous other related conditions, like port and refueling limits.

International trade is on the ascent and includes an expanding number of players such as including importers, exporters, traders, banks, insurance agencies, non-government associations and open bodies at both national and international levels (Sengupta \& Bhagabati 2003). In any transaction where goods are bought and sold, there is a transfer of ownership. Kanemoto et al. (2011); the different gatherings require bolster from a free outsider to give consolation of the congruity of merchandise. They likewise require snappy announcing from the field about quality, weight or any other part of the item. This is made more confusing by the way that the exchange is occurring crosswise over various nations. The different gatherings require ensures from an autonomous outsider to console them of the similarity of products. These administrations are offered at any phase of the generation procedure and all through the inventory network.

With expanding globalization (McMillan, Rodrik \& Verduzco-Gallo 2014), vehicle manufacturers have been re-building their production plant networks throughout the world. To ensure optimum cost saving, certain nations frequently spent significant time in the production of models. This has offered ascend to an unavoidable pattern in transporting vehicles from production nations to the consumer markets. Mann (2012) expressed amid such adventures that vehicles are liable to shifting degrees of harm all through the production network. Apart from the expense of repairing harm, such occurrences have some exorbitant reactions: deferred conveyance time to conclusive client, higher protection costs, and a negative effect on brand image. The international shipping industry oversees the carriage of around $90 \%$ of world trade and is essential to the working of the worldwide economy. Without intercontinental trade (shipping), the mass transport of crude materials and the import/fare of reasonable nourishment and merchandise would not be conceivable (Czinkota et al. 2009). It is the accessibility, 
minimal effort and effectiveness of maritime transport that has made the best move towards mechanical production in most developing countries, which has in extensive part been mindful, as of late, for sensational upgrades in worldwide expectations for everyday comforts. Despite the ongoing compression in trade coming about because of the present monetary downturn, the world economy is required to proceed to develop and shipping should react to the interest for its administrations (except if existing examples of worldwide trade were to be on a very basic level changed).

Shipping is an intrinsically international industry which relies upon a worldwide administrative structure to work proficiently. On the off chance that a ship trades from Brisbane to Buenos Aires, similar tenets need to apply (for instance: concerning development, route or climatic emanations) at the two closures of the voyage. Generally, there would be mayhem and genuine wastefulness. For more than 50 years, this worldwide administrative structure has been effectively given by the United Nations International Maritime Organization (IMO). Most nations create more income through international trade or by exporting their goods and service (Teece 2010). Governments on alternate hands can utilize trade boundary to confine the stream of products into or out of their regions. Trade barriers can take diverse structures and they comprise of tariffs, quotas, subsidies and embargoes. These barriers are most filled in as a protectionist device as opposed to an apparatus to advance organized commerce in different nations.

In any case, international organizations, for example, the World Trade Organization's aim to annihilate these trade barriers have not been exceptionally effective. Frequently, developing countries pay significantly higher transportation costs than developed countries, yet these countries get the lower wages. These trade barriers are utilized to confine international transportation and henceforth shipping industry. The examination consequently looks to assess how international trade affects the shipping industry and investigate measures undertaken by the country to facilitating international trade.

This study sought to accomplish the under listed objectives (a) and questions (b).

1a. To assess key programs implemented over the past decade to enhance international trade between Ghana and the world.

1b. Has there been any program effectively implemented to enhance international trade in Ghana?

2a. To ascertain the factors that enhance international trade in Ghana.

2b. What factors are accountable for facilitating international trade in Ghana?

3a. To identify the factors that hinder international trade by shipper's authority in Ghana.

3b. What factors are responsible forth in hindering international trade by shippers' authority in Ghana?

\section{Literature review}

\subsection{Trade Facilitation}

In specific transactions, various controls and strategies should be watched. As per Sengupta \& Bhagabati (2003) for trade and industry the expense of consistence with such controls and systems might be high, much higher than the expense of duty paid. Techniques and directions are more in international trade than in residential trade, prompting higher transaction cost for international trade. United Nations Conference on Trade and Development (UNCTAD) evaluated that the normal traditional transaction includes 20-30 unique gatherings, 40 documents, 200 information components (30 of which are rehashed somewhere at least 30 times) and the re-keying of 60$70 \%$ of all information in any event once. Systematic rationalisation of strategies and documents for international trade is, therefore, an important improvement plan.

Sengupta and Bhagabati (2003) conducted a study on the Asia Pacific Economic Cooperation. (APEC) and estimated that trade facilitation programmes would generate gains of about $0.26 \%$ of real Gross Domestic Product (GDP) to APEC, almost double the expected gains from tariff liberalization, and that the savings in import prices would be between $1-2 \%$ of import prices for developing countries in the region. This background illustrates why interest in trade facilitation is on the increase, particularly in international trade.

In a narrow sense, trade facilitation efforts could simply address the logistics of moving goods through ports or more proficiently moving documentation related to cross-outskirt trade. Lately, the definition has often been widened to incorporate the environment in which trade transactions take place. This incorporates transparency and professionalism of customs and regulatory environments, as well as harmonization of measures and conformance to international or local regulations. According to Sengupta and Bhagabati (2003), the Kelkar Committee Report defined trade facilitation as: "Trade facilitation revolves around the decrease of all the transaction costs associated with the enforcement of legislation, regulation, and administration of trade policies. It involves several agencies such as customs, airport authority, port authority, central bank, trade ministry etc., and its major objective is to reduce the cost of doing business for all parties by eliminating unnecessary administrative burdens associated with bringing goods and services across borders. This means to achieve these objectives are the modernization and automation of clearance procedures to establish international standards.

Trade facilitation is vividly explained in the World Trade Organisation (n.d) and the question of definition of trade facilitation is a highly debated issue in the WTO. Members have indicated several areas as the prime 
subject of trade facilitation, e.g.: "For the majority of developing countries, trade facilitation meant effective market access for the products of their export interest". "Trade facilitation encompasses many things, and that market access was the most important of all" (Lang 2007).

\subsection{Historical Background to International Trade in Ghana}

Ghana (Gold Coast) often recalls issues of military intervention in policies and economic mismanagement, but such issues were more prevalent between 1957 and 1982 (Hettne \& Söderbaum 1998). The development policies and strategies adopted by the first post-independence government of President Kwame Nkrumah (1957-1966) were a blend of Western Bloc modernization and industrialization and Eastern Bloc socialism, emphasizing the role of the state in directing economic development. Successive governments followed in Nkrumah's footsteps, although distinct changes did occur in policy and planning strategies.

Not as much as 10 years after freedom, Ghanaians especially the nation's political pioneers, understood that political independence was not an assurance for financial independence and prosperity. The need for economic and political cooperation with Britain and Her allies was indispensable. Ghana was beforehand connected to the economies of Europe through outside trade with Portuguese, Danish, French and Dutch vendors and teachers and by its status as a British settlement political independence did not server these linkages. Rather, both exportarranged and import substitution techniques of advancement were vivaciously pressed together. International reliance was ensured through export cocoa, timber and minerals, import of capitals merchandise for the venture and utilization products for the extending populace and the requirement for specialized aptitude and money related guide (Boahen 1975). International relationship has not, nonetheless, met Ghana's development needs. Ghana's outer trade execution was not great in the 1970s and mid-1980s.

The domestic problems of rapid population growth, political instability, corruption, high inflation rates, economic mismanagement and a lack of confidence in government policies have also negated Ghana's economic development. The 1970s and early1980s saw a huge cerebrum depleting of savvy people and experts to different nations in look for better openings for work and living conditions (Gould 1990; Kapur et al., 1991). Since 1983, the government has invested much exertion to protect the economy through basic changes (the Economic Structural Program, ESP) prescribed and upheld by the World Bank and the International Monitory Fund (IMF). The ESP has included that an expanded privatization of profitable areas of the economy, conversion scale alterations of the Ghanaian money, institutional working to change, open division conservation, showcase assurance of costs and loan fees, and trade advancement favoring expanded exports and imports (Bentsi-Enchill 1988; Kapur et al. 1991; Asmah et al.1993).

Products sent to the international market by Ghana are mostly agricultural, processed and semi-processed, and handicraft products have been accorded unparalleled attention by the government within the context of the ERP. This dedication was required by the exacerbating terms of trade for the nation's conventional exports. Products, for example, pineapples, mangoes, crisp chilies, okra, beans, rubber yam, cassava (manioe), fish, shrimps, pawpaw, avocado pear and plantains are a portion of the farming products in Ghana. The prepared and semi handled things include furniture parts, facade, plywood, wooden toys, aluminum utensils, canned products of the soil, chocolate, basic salt, agrarian actualizes and sustenance preparing machines; and crafted works incorporate ornamental earthenware production, floor tiles, dots, materials, for example, "kente" and batik, carvings, container products (stick, straw and bamboo) and gems (GEPC, 1987).

\subsection{Impact of International Trade in Ghana}

Consistently the world is developing ever nearer together. Nations depend on each other for assets that they don't have access to them generally. Along these lines, they should trade with each other to get what they require. This enables organizations to venture into new markets all over the world. Thinking about the economic downturn, it is staggering that most countries have kept up a high position in the worldwide market, a position that keeps on invigorating the state's financial prosperity and development international trade is important or fundamental since it gives:

a. Economic Growth: International trade represents almost 25 percent of most developed countries' economy. Especially in USA, it was viewed in 2011 that there was a significant increment in compartment volume at the Port of Los Angeles, the biggest port in the United States. "With this 16 percent expansion in 2010 holder volumes, the Port of Los Angeles is giving individuals back something to do and doing its part to help President Obama meet his objective to twofold national exports throughout the following five years," said Antonio Villaraigosa, leader of the City of Los Angeles. "This is uplifting news for Los Angeles, as well as for urban areas the country over". California's economic future is as yet obscure; however, the state has thrived through continuous monetary development since for the least purpose of the budgetary emergency. Keeping up and expanding upon this level of development in international trade will demonstrate fundamental, as a fourth of the state's economy relies upon it.

b. Job creation: Current figures for employment development in many nations are optimistic. Albeit, most of the 
nations may not be at the ideal level of employment for a perfect occupation advertise, there is no denying that the normal lessening in unemployment is empowering. In the United States, the current statewide unemployment rate of 12.4 percent should drop to 11.4 percent before the end of 2011 and to 10.4 percent before the end of 2012. The World Bank in its latest report on jobs in Ghana has revealed that about 48 percent of the youth in the country, who are between 15-24 years do not have jobs. The report dubbed the "Landscape of Jobs in Ghana," explores the opportunities for youth inclusion in Ghana's labour market. "In Ghana, youth are less likely than adults to be working: in 2012, about 52\% of people aged $15-24$ were employed (compared to about $90 \%$ for the 25-64 population), a third were in school, $14 \%$ were inactive and 4\% were unemployed actively looking for a job. c. Provision of new ideas: It allows countries to get new ideas from one another, it allows countries to resources that they need, and it reduces the risk of an economic collapse. International trade allows countries to learn from each other and take in new ideas (MacBain 2008). One country might be focused on developing one type of product while other maybe focusing on a completely different subject. Together, they can share their ideas, benefiting both economies of both countries.

d. Availability of resources: International trade is needed between countries because resources that a country needs are not available everywhere. This enables countries to export resources that are not at their disposal from other countries. For example, the United States imports lots of oil from countries in other continents. Resources do not have to be material goods but can also be labor related as well. Lots of companies take their factories overseas because labor tends to be much cheaper over there. Because of this, they can produce their products for a much lower cost, increasing their profitability. This helps both the company producing the products as it lowers their cost, but also helps the people doing the labor, as it provides a place of employment for them.

e. Reduction of economies risk: Yet another reason why global international trade is necessary is that it reduces the risk for one economy. If one economy must deal with everything, and if it ever collapses, the country will fall apart. By trading internationally, countries rely on one another and it creates a balance amongst them. If one country's economy is doing very well, then the economies of other countries that trade with it tend to be doing well also. If a country falls on hard times, but other countries might also suffer. An example of this is the current credit situation the United States. Countries around the world were affected by the credit problem because a lot of them loaned money to other countries.

\subsection{History of Ghana Shippers Authority}

For over 35 years, the Ghana Shippers' Authority (GSA) which was established in 1974, operated under the corporate name Ghana Shippers' Council which by virtue of The Laws of Ghana (Revised Edition) Act 562 (1998), was changed to Ghana Shippers' Authority. The change in name takes care of the transformation that the Council has seen over the years and brings it in tune not only with the Constitution of the Republic of Ghana but also in accord with the dynamics of modern shipping practice as far as the demand side of shipping is concerned. The Authority has over the years collaborated with private and public organizations in the maritime industry to pursue its primary objective of protecting and promoting the interests of Ghanaian shippers in relation to port, ship and inland transport problems in order to ensure safe, reliable and cost-effective cargo handling. The GSA operates under the ministerial responsibility of the Ministry of Transport and has a three-tier organisational structure. The governing board of the shippers' authority is made up of institutional representation of various importers and exporters as well as government agencies responsible for maritime trade and transport.

The Governing Board works through its Technical Committees of Finance \& Administration, Freight \& Logistics and Ports \& Infrastructure for the achievement of its objectives.

\subsection{Services Provided to Shippers}

The shippers' authority provides various services to shippers. Services such as the resolution of shippers' conflict, Job shippers' complaints and support unit, legal assistance and support units, legal assistance and arbitration, call centre, mobiship, and bulk SMS are discussed below.

\section{a. Resolution of shipper complaints}

The GSA has been at the forefront of intervening, investigating and finding solutions to shippers' challenges and complaints daily in respect of loss/damage to cargo; Cargo insurance claims; late arrival of shipping documents; Illegal charges levied on shippers, etc. As part of efforts at finding solutions to the challenges and problems confronting shippers about their shipments, the GSA regularly tours and monitors operations at the country's ports to identify bottlenecks in the clearing and forwarding system. These problems are reported to the Ghana Ports and Harbour Authority and other port operators for speedy resolution. The GSA also participates in the daily berthing meetings at the ports. These meetings afford stakeholders in the maritime industry the opportunity to make inputs in the planning of daily port operations.

\section{b. Shipper Complaints and Support Units}

The GSA has commenced the establishment of Shipper Complaints and Support Units at strategic points of the country's entry points in order to provide real-time assistance to shippers who use those points and find solutions 
to the challenges confronting them in the course of their business transactions. Four of the units at the Elubo border, Takoradi Port, Aviance Cargo Village at the Kotoka International Airport, and the Aflao Border have been established and are in full operation. The GSA intends to replicate the Units at Paga and Bawku to offer shippers readily available assistance in the clearance of goods at these entry points. The establishment of the Units was in response to increasing requests by shippers for the GSA's presence at the entry points of other modes of transport that serve Ghana's international trade, namely, road, sea and air.

\section{c. Legal Assistance and Arbitration}

The GSA also arranges some level of legal services for shippers with legitimate maritime claims. It mediates between users and providers of shipping services on legitimate shipping trade disputes.

\section{d. Call Centre}

The GSA has also established a call centre which serves as a central clearing point of challenges and problems confronting shippers. A toll-free hotline $(0800$ 30005) has been installed to reinforce communication with importers, exporters, business and the shipping public. The facility assists the GSA in responding promptly to the enquiries of shippers.

e. Mobiship

GSA has taken advantage of developments in mobile phone telecommunication to place its vessel movement schedule, code named Mobiship on all the mobile telephone networks in the country. This has enhanced accessibility to the vessel movement schedule which for years has assisted shippers in planning their shipments. Mobiship can be accessed via all the mobile phone networks across board.

\section{f. Bulk SMS}

In line with its strategy of reaching shippers through innovative technologies, the Authority has acquired and installed a new text message processing software at its Head Office. This facilitates the dissemination of timely and relevant information for importers and exporters who have registered with the Authority.

\subsection{Strategies and Options for Sustainable Shipping and Port Development}

The Shipping and Port Industry have started to recognize that sustainability is good for profitability and to respond to the growing environmental and social concerns of clients and the communities in which it operates. In the past years shipping companies, port operators and authorities, port and shipping associations, research institutes, and government and environmental agencies have developed and implemented strategies, initiatives and programs, tools, guidelines and systems that address issues related to sustainable shipping and port operations and environment. These are concerned with air quality, climate change, water quality, waste handling, dredging, energy, conservation and renewable energy, natural resources, sustainability and environmental management systems (OECD 2003).

These lead to the selected organizations, associations and agencies and the policies strategies, initiatives, programs, tools, guidelines and systems they have developed during recent years that may assist in decisionmaking processes orientated towards sustainable development in the shipping and port industry. The main drivers for achieving improvements are environmental management systems, policy instruments, application of innovative technologies or a mixture of them (UNCTAD 2009).

\subsection{Private Sector Participation}

According to Braid (1999) defining privatization is seldom easy and mostly needs analysis to arrive at a suitable definition. This therefore means that privatization cannot be defined for each port is unique and therefore will have needs. Braid (1998) went on to say that for an identification of what one means by port privatization it is better to identify the main components of a port that can be privatized. These components of a port are those that can be privatized either collectively or on individual basis;

i. Port regulator

ii. Port landowner

iii. Port operator

The typical port operators' function as indicated by Baird (1995) are as follows;

a) Maintaining the conservancy function; which include ensuring that the navigational ways are maintained and where necessary improved while ensuring that the appropriate fees are paid by the shipping companies.

b) Performing pilotage services and vessel Traffic management; which is generally termed VTS which also ensure that craft use safe passages and defined areas of jurisdiction.

c) Enforcement of applicable laws; this is to ensure that health and safety standards are maintained. This is done through the creation of the ports own fire and police force.

d) Licensing of port work; this function becomes the tool of the port authority to either encourage or discourage certain projects within the authorities' jurisdiction.

e) Safeguarding port users from the risk of monopolies; this is to ensure that the port user is treated in a 
fair manner; the port authority is expected to be a natural monopoly and therefore treat port users equally.

The second function that could be privatized is the estate management or land ownership of the port environment. Next to the municipal authorities, port authorities are the second largest owners of land within the port community. De Monie (1994) indicated that whether small or large, port landowners are expected to perform the following functions;

a) Manage and develop the port estate,

b) Conceive and implement port policies and development strategies,

c) Supervise major civil engineering works

d) Provide and maintain channels fairways, breakwaters etc.,

e) Provide and maintain locks, turning basins, piers and wharves and

f) Provide and arrange road access to port complex.

\section{Methodology}

The study used the Ghana Shipping Authority (GSA) where information or data was obtained to answer the research objectives. Thus, the research is a case study which focuses on the GSA on one aspect of a problem which traces the in-depth knowledge of the subject under investigation.

The research used questionnaire as the main instrument to obtain the necessary information for the study and in this both close and open-ended questions were used. As such a blend of qualitative and quantitative research design was used to make it flexible for the researcher to gather enough data for the study. The target population for this study was persons at various levels of management of Ghana Shipping Authority (GSA).

Thirty (30) questionnaires were administered to selected persons at the GSA. The thirty people were selected using purposive sampling technique. Purposive sampling is a non-probability sampling technique where units are selected based on the researcher's knowledge of the population and the interest of the researcher. This method was used so that the researchers can select persons who have the best knowledge of practices and operations at the GSA.

The data analysis commenced with the collection of all administered questionnaires and responses were edited for correction. The close-ended questions were assigned discrete numerical values for input into computer software packages for analysis. The open-ended questions were all examined for each questionnaire to determine possible patterns or themes for classification. Then discrete numerical values were assigned to the classified responses to make them easy to analyse using computer software programmes.

After processing the raw responses from the questionnaires, SPSS and Microsoft Excel were used to run the analysis of the processed data. Descriptive statistics and frequency distribution were used to examine and explain the results of the analysis. Descriptive statistics involve the use of mean, mode, median and standard deviations whilst frequency distribution involves the use of percentages, tables, and graphs (line graph, bar chart, pie chart etc.) to show the distribution of the responses. The results of the analysis were used to answer the research questions. The responses that were heavily narrative or textual were included in the findings to help answer the research questions.

\section{Analysis and Interpretation of results 4.1 Age of Respondents Distribution}

The age distribution of respondents is shown in figure 4.1. Respondents were to indicate their age in each of the following: $20-29$ years; $30-39$ years; $40-49$ years; $50-59$ years; above 60 years.

From the figure $17 \%$ are within 20 to 29 years of age; $33 \%$ fall within 30 to 39 years; $27 \%$ are within 40 to 49 years; $23 \%$ are within 50 to 59 years of age. None of the respondents were above sixty years.

\subsection{Educational Qualification}

Most of the respondents have a postgraduate or professional qualification; all the respondents at least have a Diploma or a High National Diploma. From the figure below, $47 \%$ of the respondents indicated they have postgraduate qualification, $33 \%$ have graduate or first-degree qualification, and $20 \%$ have a High National Diploma or just a Diploma. See figure 4.2

\subsection{Length of Service at GSA}

Most of the respondents who took part in this study have worked at the Ghana Shippers' Authority for not more than five years compared to those who have served for more than twenty years. $27 \%$ of the respondents say they have served for not more than five years as against $20 \%$ who have worked for more than 25 years. From figure 4.3 it can be observed that $23 \%$ have worked between 6 to 10 years; $20 \%$ have worked between 11 to 15 years; $7 \%$ have worked between 16 to 20 years; and 3\% have worked between 21 to 25 years. It can also be observed that most of the respondents have worked for less than 15 years compared to those who have worked for more 
than 15 years. This analysis simply tells how well inform the respondents are towards the areas under researched.

\subsection{Departments/Unit of Respondents}

The distribution of respondents in the departments or units at the Ghana Shippers' Authority is shown in the frequency distribution table below. It can be seen from table 1 majority of the respondents are from the finance department/unit while the least respondents came from the management and information, human resource, and legal and audit departments/units each with 7\%. 13\% of the respondents each are from the Freight and Logistics and Shippers' Services departments/units; 10\% are from the Research and Development; 23\% are from Finance and $20 \%$ are from Public Relations.

\subsection{Trade Enhancement Programmes}

The Ghana Shippers Authority is financed mostly through its coffers generated through revenues from its operations, publications and warehousing. This section looks at the programmes or initiatives that the government of Ghana or the Ghana Shippers' Authority has instituted if any over the last decade to enhance international trade. All respondents were given the opportunity to indicate initiative implemented of which they are familiar. All the respondents at least stated one initiative or programme that has been implemented to enhance the authority's activities. And according to the respondents most of these programmes have achieved the aims for which they were implemented partially or fully. The programmes that featured prominently, and their respective outcomes are listed in the table 4.5.

\subsection{Government Intervention Programmes}

The Government has over the decades been helpful to the shipping industry and the Authority according to respondents. Among the intervention programmes the government has implemented, sometimes collaborates with the GSA; these are,

- Creation of an enabling environment for the GSA to operate which includes regulation to empower the Authority to operate

- Construction of railways to facilitate transport of goods

\subsection{Challenges Facing the GSA}

According to the respondents, the challenges most prominently facing the Ghana Shippers' Authority and the shipping industry are:

- Long clearance process at ports and high duty rate

- Bureaucracy on the part of government on the part of government

- High cost of tariffs

- High illiteracy rate among shippers

- Differences in trade policies, especially among the ECOWAS community

- Language barriers, currency differences and conversion problems. Thus, exchange rate

- Risk of cargo and goods

Government policies that also hinder the operation of the GSA and the shipping industry are trade tariffs, quotas and trade embargos.

\section{Conclusion}

Ghana Shippers Authority like any other organization faces some challenges in their operation. These problems can come from the government, the industry, other countries and customers. The problems which are frequently faced by the shipper's authority are Long clearance process at ports and high duty rate, Bureaucracy on the part of government High cost of tariffs, High illiteracy rate among shippers, Differences in trade policies especially among the ECOWAS community, exchange rate which involves Language barriers, currency differences and conversion problems and risk to cargo and goods. The government policies that hinder the operation of Ghana shippers' authority are trade tariffs, quotas and trade embargos. The study recommends that government and the Authority as well as all stakeholders should help to provide resting points for drivers at vantage points. Strict enforcement of government policies intended to enhance the operations of the shipping industries and that must stop. Measures should be put in place to ensure that the GSA meets all international standards. Efficient communication systems should be ensured among Ghana and its landlocked neighbours and other trading partners as well as the government and GSA.

\subsection{Recommendations}

The following are the recommendations that respondents gave to help facilitate the operations of the Authority and the shipping industry. 
- That government and the Authority as well as all stakeholders should help to provide resting points for drivers at vantage points.

- There should be a reasonable reduction of import charges to facilitate trade with diverse and different geographical areas of the world.

- Strict enforcement of government policies intended to enhance the operations of the shipping industries.

- Measures should be put in place to ensure that the GSA meets all international standards.

- Efficient communication systems should be ensured among Ghana and its landlocked neighbors and other trading partners.

\section{Tables and Figures}

Figure 4.1: Age Distribution of Respondents

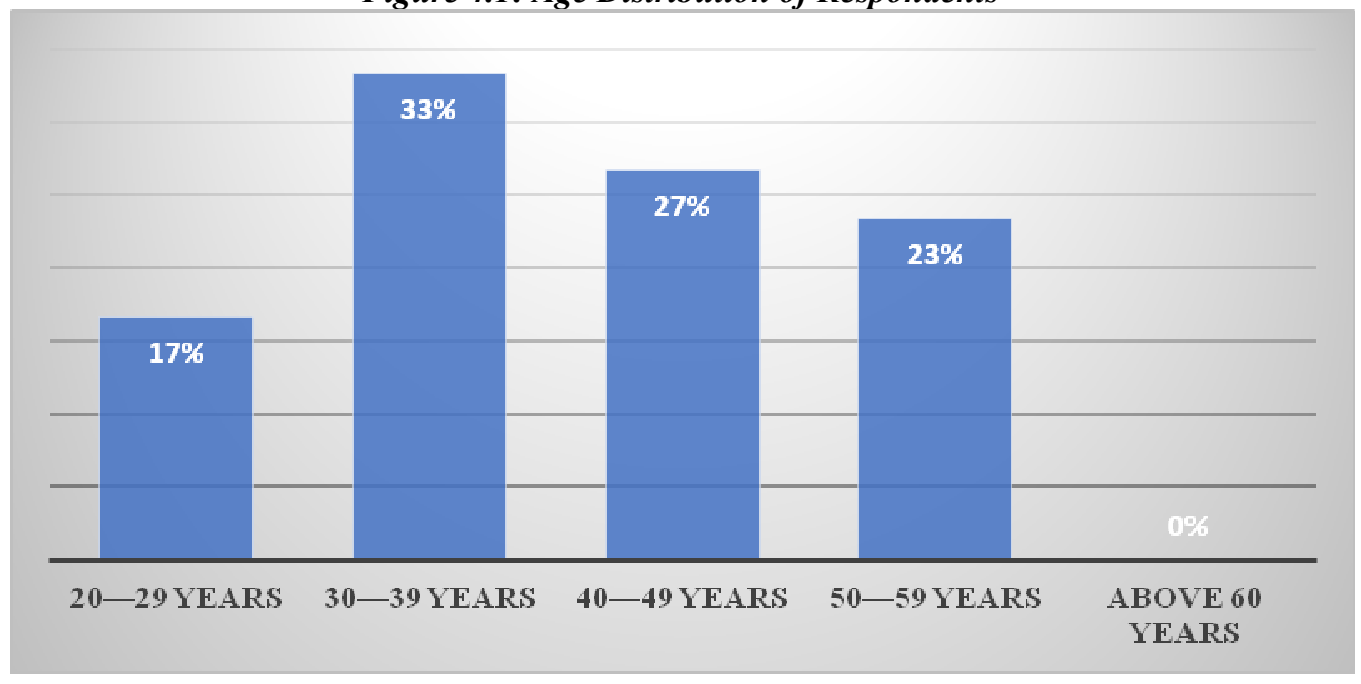

Figure 4.2: Educational Qualification

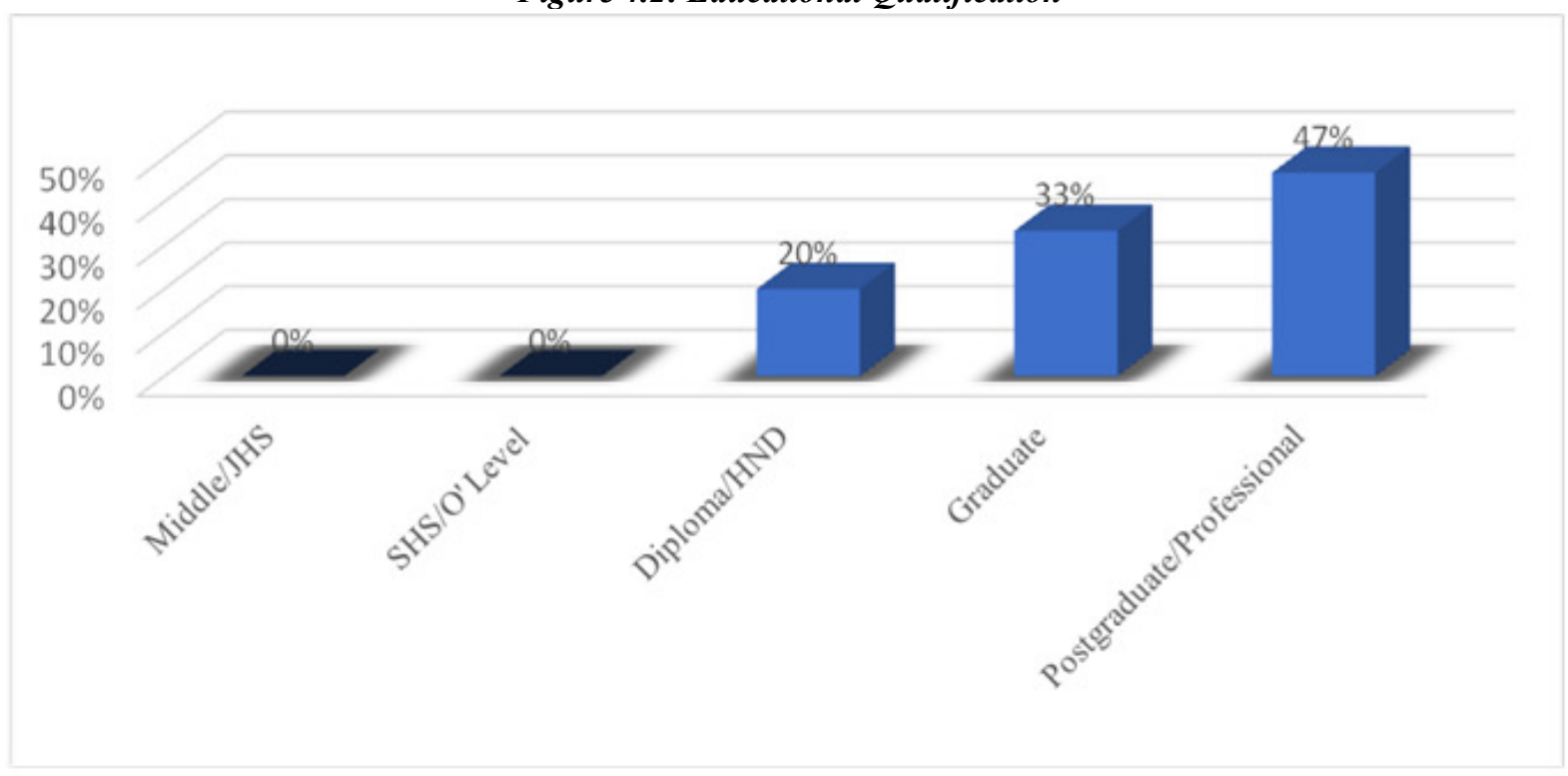




\section{Figure 4.3 Length of service with GSA}
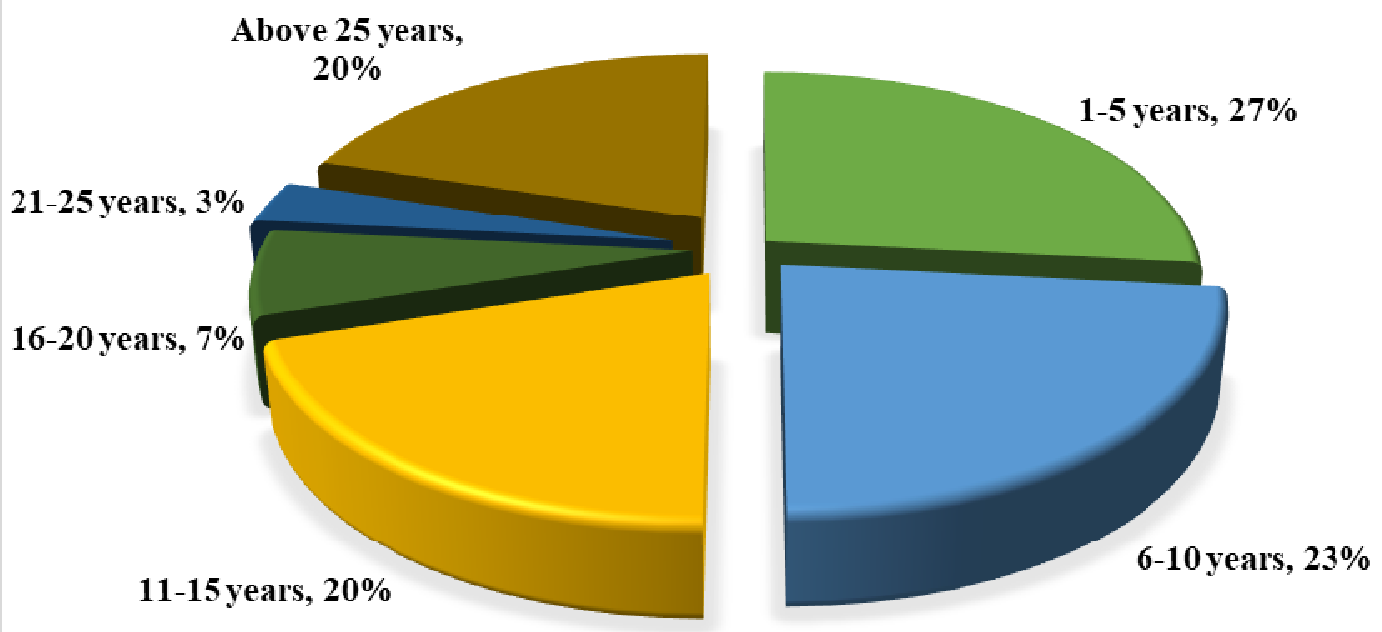

Table 4.4: Department/Unit distribution among respondents

\section{Department/Unit}

Freight and Logistics

Research and Development

Shipper Services

Management Information Systems

Finance

Public Relations

Human Resource and Administration

Legal and Audit

\section{Frequency}

$\begin{array}{lc}4 & 13 \\ 3 & 10 \\ 4 & 13 \\ 2 & 7 \\ 7 & 23 \\ 6 & 20 \\ 2 & 7 \\ 2 & 7\end{array}$

Source: Survey Data, 2015

Table 4.5: Programmes/Initiative of the Ghana Shippers Authority

\begin{tabular}{|c|c|}
\hline Programmes/Initiative & Outcome/Expected outcome \\
\hline $\begin{array}{l}\text { Memorandum of understanding with } \\
\text { landlocked countries in West Africa and the } \\
\text { Union of Africa Shippers' Countries }\end{array}$ & $\begin{array}{l}\text { - Road transport system integration } \\
\text { Harmonization of shipping and transport policies, } \\
\text { axle load regime } \\
\text { Harmonization of the Juterstate Road Transportation System } \\
\text { Common Stand at major international forum like MOWCA, } \\
\text { IMO and World Shippers' Forum }\end{array}$ \\
\hline $\begin{array}{l}\text { Ghana Community Network (GCNet) Services } \\
\text { Limited }\end{array}$ & $\begin{array}{l}\text { - It enables quick processing of all customs clearance } \\
\text { documentation online } \\
\text { - It facilitates clearance of goods through the ports } \\
\text { It increases speed and transparency in the clearing } \\
\text { process and ensures the right revenue that accrues to } \\
\text { Government. } \\
\text { - It enables the Authority access important maritime } \\
\text { data for its research work and the publication of its } \\
\text { journal Shipping Review, and Digest of Maritime } \\
\text { Statistics }\end{array}$ \\
\hline $\begin{array}{l}\text { Maritime law Seminar for judges, business and } \\
\text { shipping programmes aimed at judges and } \\
\text { journalists }\end{array}$ & $\begin{array}{l}\text { - Proper understanding of the activities of the shipping } \\
\text { - Better reportage by the media on the activities within } \\
\text { the maritime sector/enhancement of the image of the } \\
\text { GSA } \\
\text { - Smooth adjudication of shipping related cases in the } \\
\text { court }\end{array}$ \\
\hline
\end{tabular}




\section{Programmes/Initiative}

Boankra Inland Port Establishment to reduce shipment and increase productivity. This initiative is aimed at reducing aggregated travelling costs of importers and exporters in the geographically disadvantaged nations such as Mali, Niger and Burkina Faso

Warehousing programme to enhance storage and boost trade partnership

National Shippers day for Ghanaian Shippers

Axle Load Limit (Axle Load Control Policy)

Sealed Grid System (SGS)

Source: Survey Data, 2015

\section{Reference}

Asmah, R., Wan Zurinah, W.N., Abdul Gapor, M.T. and Khalid, B.A.K. (1993). Long-term tocotrienol supplementation and glutathione-dependent enzymes during hepatocarcinogenesis in the rat. Asia Pac JClin Nutr, 2, pp.129-134.

Bauman, R. and Braid, D. (1998). The ethnography of performance in the study of oral traditions. Teaching Oral Traditions, pp.106-122.

Bentsi-Enchill, N. (1988). No Place for the Masses. West Africa, 3704, pp.1428-1429.

Boahen, A.A. (1975). Ghana: Evolution and change in the nineteenth and twentieth centuries. Addison-Wesley Longman Limited.

Buyonge, C. and Kireeva, I. (2008). Trade facilitation in Africa: challenges and possible solutions. World Customs Journal, 2(1), pp.41-54.

Czinkota, M.R. and Ronkainen, I.A. (2009). Trends and indications in international business. Management International Review, 49(2), pp.249-265.

Gould, S.J. (1990). Wonderful life: The Burgess Shale and the nature of history. Norton \& Company.

Hettne, B. and Söderbaum, F. (1998). The new regionalism approaches. Politeia, 17(3), pp.6-21.

Kapur, P.A., 1991. The big "little problem". Anesthesia \& Analgesia, 73(3), pp.243-245.

Kanemoto, K., Moran, D., Lenzen, M. and Geschke, A. (2014). International trade undermines national emission reduction targets: New evidence from air pollution. Global Environmental Change, 24, pp.52-59.

Lang, A.T. (2007). Reflecting on 'linkage': cognitive and institutional change in the international trading system. The Modern Law Review, 70(4), pp.523-549.

McMillan, M. and Rodrik, D., I. Verduzco-Gallo (2014). "Globalization, Structural Change, and Productivity Growth, with an Update on Africa". World Development, 63(1), p.1.

Mann, M. (2012). The sources of social power: volume 1, a history of power from the beginning to AD 1760 (1). Cambridge university press.

Tomlin, B. and Wang, Y. (2011). Operational strategies for managing supply chain disruption risk. The handbook of integrated risk management in global supply chains, pp.79-101.

Teece, D.J. (2010). Business models, business strategy and innovation. Long range planning, 43(2-3), pp.172194.

Sengupta, N. and Bhagabati, M. (2003). A Study of Trade Facilitation measures. Interim Report, Madras Institute of Development Studies", Chennai.

Schuppan, T. (2009). E-Government in developing countries: Experiences from sub-Saharan Africa. Government Information Quarterly, 26(1), pp.118-127.

\footnotetext{
About Authors

Stevens. Justice Avenyo is currently an Assistant Lecturer in French at the University of Professional Studies, Accra, Ghana - West Africa. He has developed passion for teaching and research works in diverse areas such as Media, Language and Communication, Language and Sociolinguistics, Global Business (Maritime) among others because of his diverse educational backgrounds. He is a $\mathrm{PhD}$ candidate at the University of Cape Coast, Ghana, in French Didactics and Teaching French as a Foreign Language. His research work would focus on teaching and Learning French for Specific Purposes for effective business communication and innovations.

Andrews Seidu Achana is Director of Spartan Consulting Group Gh. He holds a Degree in Banking and Finance from the University of Professional Studies, Accra. He is a Research fellow and works with various organizations on business projects. He is a business coach and mentor to various university students. His research features work on antecedents of leadership, maritime, media, administration, Finance, marketing and theology.
} 